\title{
Development of Folklore Teaching Materials Based on Local Wisdom as Character Education
}

\author{
Suherli Kusmana $^{1, ~ *}$, Jaja Wilsa ${ }^{1}$, Ipit Fitriawati ${ }^{2}$, Fithry Muthmainnah ${ }^{3}$ \\ ${ }^{1}$ Postgraduate School, SwadayaGunungJati University, Cirebon, Indonesia \\ ${ }^{2}$ Vocational High School Cendekia, Cirebon, Indonesia \\ ${ }^{3}$ Vocational High School Maritim NU Kamplongan, Indramayu, Indonesia
}

Email address:

suherli2@gmail.com (S. Kusmana)

*Corresponding author

\section{To cite this article:}

Suherli Kusmana, Jaja Wilsa, Ipit Fitriawati, Fithry Muthmainnah. Development of Folklore Teaching Materials Based on Local Wisdom as Character Education. International Journal of Secondary Education. Vol. 8, No. 3, 2020, pp. 103-109. doi: 10.11648/j.ijsedu.20200803.14

Received: August 31, 2020; Accepted: September 16, 2020; Published: October 12, 2020

\begin{abstract}
This study aims to overcome the problem of limited teaching materials for Indonesian subjects in vocational high schools, especially about folklore. The method used in this research is research and development. The results obtained by folklore that developed in the Cirebon and Indramayu districts have moral values and are close to students' lives so that they are suitable for use as teaching material. The folklore analyzed has structure, linguistic elements, and moral values so that it can be used as a basis for the development of folklore teaching materials but by adjusting the use of language. The development of folklore teaching materials is adjusted to the achievement of basic competencies validated by experts and practitioners to get a classification as teaching materials that are suitable for use in vocational High School in the Cirebon and Indramayu regions. Based on the results of the learning trials it is known that these teaching materials can be used effectively in improving students' ability to produce literary works, especially short stories by using basic ideas from folklore. Teaching material developed is more interesting for students 'interest and enthusiasm, because the teaching material is in accordance with the students' cultural background. The students' responses to teaching materials were very enthusiastic when presented teaching materials that came from folklore from the Cirebon area, aroused curiosity, and learning activities took place dynamically and students did not feel fed up.
\end{abstract}

Keywords: Folklore Teaching Materials, Local Wisdom, Character Education

\section{Introduction}

At present the teaching materials of folklore texts presented in textbooks are only presented in the form of saga, whereas the types of folklore that develop in the archipelago vary greatly depending on the cultural development of a society. If the material is about folklore, only the type of saga is presented, so high school students from outside Sumatra are less familiar. Whereas in the vicinity of the student's environment there are also available folklore, both those that have been printed or are still oral (folklore) related to the name of an area.

In the cognitive development of students, if the folklore that is the teaching material is related to the name of an area around the student's residence will be able to bring the understanding of high school students closer to the understanding of the structure and language aspects of folklore texts [1]. In the development of psychomotor abilities, it is not possible in at the end of the lesson students develop folklore, but what is most possible is to develop ideas or ideas from folklore as inspiration that can be developed into a short story. Thus, the development of student creativity can be built through the development of attitudes by training students to implement the values of local wisdom of a folklore into the short stories they make [2].

Teaching materials that teach moral values can be extracted from the local wisdom of a community. Local wisdom can be obtained from folklore. These moral values can be inherited through education in the form of character education [3]. Character as a noble character or moral excellence is built on various virtues (virtues) which in turn 
only have meaning when based on values that apply in the culture of a nation. The character of the Indonesian nation is the character possessed by Indonesian citizens based on actions considered as virtues based on values prevailing in society. Values that apply in culture as local wisdom, which can be obtained from folklore as a cultural heritage $[1,4]$. These cultural heritage values can be developed as teaching materials, because the development of teaching materials that are relatively new is still being done $[5,6]$ including those extracted from the field and the environment.

Folklore is one of the cultural heritages that develops and lives in the community. The types of folklore consist of three major groups, namely: (1) myth (myth), (2) legend (legend), and (3) folktale [7]. Folklore as a literary work that has a structure and values for its readers is very good when applied in learning to students. From this learning in addition to students getting to know local wisdom in their area, the development of teaching materials extracted from local wisdom will be very beneficial for students in linking teaching materials based on the social context of the community [3]. The folklore can be studied for its structure so that it can be used as teaching material that has positive values and provides many benefits to students $[2,8]$. The values contained in folklore need to be maintained and passed on to future generations. As a legacy or heritage, local wisdom is a great cultural wealth and tradition that must not only be preserved or preserved, but must also be applied in daily life.

In this connection, folklore as one of local wisdom can be analyzed based on literary structure and literary values as the constructor [1, 4]. The results of this analysis can then be developed into teaching materials in Indonesian language lessons in senior high schools. Based on preliminary studies, it is known that in Cirebon and Indramayu Regencies there are many folklore which is one of the community's cultures that can be used as learning material in education units. Therefore, the authors conducted research using these locations.

This paper is taken from research of the development of folklore teaching materials from the Cirebon and Indramayu regions is used as teaching material in high schools or vocational schools in Cirebon City and Regency, while the folklore teaching materials from the Indramayu region are used as teaching material in high school or vocational school in Indramayu Regency.

\section{Reference Review}

\section{Teaching Materials}

Teaching material is a set of information that students must absorb through fun learning [9]. This shows that in the preparation of teaching materials students are expected to really feel the benefits of teaching materials or material after he learned it. Teaching materials are a set of learning tools or

tools that contain learning materials, methods, boundaries, and ways to evaluate systematically and attractively designed in order to achieve the expected goals, namely achieving competence and sub competence with all its complexity [10].

Teaching materials are important things that must be available when learning is done. The availability of teaching materials will facilitate and help students and teachers in learning. Teaching material is one of the most important parts in the learning process because there is a number of information, instructions, processes, and evaluations that support learning activities to achieve goals $[2,11]$. Teaching materials are content that needs to be learned by students in the form of print or facilitated by the instructor to achieve certain goals. Teaching material is a visual and audiovisual learning resource that can be used by students as a medium of communication in the learning process [12].

Teaching material is used as a support in providing examples to students, one of which is fairytale text teaching material. A fairy tale text that has the character of heroism, intelligence, courage, and other virtues will give students an idea of some of the characteristics that need and are not exemplary. Teaching material refers to the fulfillment of four aspects, namely aspects of content, systematic aspects of presentation, aspects of language, and aspects of graphics or appearance [13].

Teaching materials should make it easier for students who have difficulty understanding learning materials, are able to meet the needs of students, information is presented to be studied by students that contain all the material or theory of learning, is complete, so that students no longer need to look for other sources of material, follow technological developments, and make it easier for users when they want to use it [14]. Thus every material, both instruction and information exposure; presentation; use of language; and the writing graphics are helpful and friendly to the wearer.

Good teaching materials not only contain knowledge, but are developed in a quality way using a theoretical foundation. For this reason, in order to produce teaching materials that are capable of carrying out their functions and roles in effective learning, teaching materials need to be designed and developed using the latest approach. Therefore, the development of teaching materials that are in accordance with the current condition of students uses the Integrated Learning and Content Learning (CLIL) approach [15], with stages: (1) establishing context, (2) examining models / examples; (3) guided construction; and (4) construct independently through scientific procedures (scientific) through a $5 \mathrm{M}$ pattern consisting of: observing, questioning, gathering information, reasoning, and communicating [16].

Folklore

Folklore is an oral tradition handed down to the community, such as the folklore Malin Kundang, Sangkuriang, Si Kabayan, and so on. The spread of folklore is done orally so that the author is unknown or anonymous, but lately there have been efforts to document in the form of written text [17]. Folklore also takes the form of utterances which function as a medium for expressing behavior about the values of life inherent in people's lives $[1,8]$.

Folklore is a genre of folklore that is spread in oral form and the story is anonymous which is not bound by space and 
time and the author's name is no longer known [8, 18]. Folklore is not only a folk story without meaning or fairy tales to put children to sleep, but folklore has a tradition of neglect, entertainment and education. Folklore not only tells the origin of the occurrence of a place but also tells about positive behavior whose presentation is adjusted to current conditions $[2,17,19]$.

Folklore is a local wisdom that has a literary text structure and has moral values as a message the writer wants to convey to the reader $[2,8]$. The moral message is tucked inside the characters' characters, messages from the character's expressions or dialogues, or from the story line. The message in folklore is in the form of advice, advice, guidance, guidance, or education to humans for noble deeds by being wrapped through folklore [19].

\section{Local Wisdom}

Local wisdom is the ideas, values or views of a place that has a wise and valuable nature that is followed and trusted by the people in that place and has been followed for generations $[20,21]$. In derivational terms, the term local wisdom (local wisdom) consists of two words, namely wisdom (wisdom) and local (local). The word "wisdom" means wisdom while the word "local" means local. Local wisdom or so-called local wisdom can be understood as a human effort by using his mind (cognition) to act and behave towards something, object, or event that occurs in a particular space $[22,23]$. Thus, local wisdom or local wisdom can be understood as local ideas and knowledge that are wise, full of wisdom, of good value, and virtuous that are owned, guided, and implemented by members of the community.

Prototype teaching materials folklore texts compiled based on the needs of students and teachers have high effectiveness in achieving goals [2, 4, 24]. These teaching materials have local significance values contained therein. Local wisdom is related to the system and the needs of human life. The local wisdom about social relations and kinship systems is implied in an atmosphere of unity of tolerance and togetherness that is manifested in real life $[15,25,26]$.

\section{Method}

The research method used is research and development as developed [27]. From this study produced valid and effective teaching material products [28] for use in learning. The research procedures undertaken include the research phase which consists of the analysis of teaching material needs, analysis of competency standards, analysis of folklore that has moral values in Cirebon and Indramayu districts, development of teaching materials, validation of folklore teaching materials, and testing of materials teach. The next stage of development consists of developing teaching materials, validation and revision of folklore teaching materials that have local wisdom [28, 29]. Finally, the evaluation stage of folklore teaching materials that have local wisdom based on limited trials to find out the effectiveness of the use of teaching materials in learning folklore material. The steps taken are:; (1) the initial analysis phase of folklore, the analysis of the textbook used, and the need for teaching materials; (2) stages of developing instructional material design and validation; (3) the stage of reconstructing the ingredients based on the input of the validation results of experts and practitioners; (4) the test and evaluation stages or limited testing of teaching materials in schools, and revise them; and (5) the implementation phase of teaching materials with a broader scope.

There are two types of research subjects, namely the subject of the analysis of the availability and condition conditions of selected folklore in Cirebon and Indramayu regencies and analysis of the need for folklore teaching materials that have local wisdom as character education. Therefore, the subjects in the research used are folklore document in Cirebon Regency and Indramayu. Meanwhile, the subject of research when validating products through evaluating prototypes of folklore teaching materials that have local wisdom is academics and practitioners of Indonesian language education. Furthermore, the research subjects in conducting the prototype testing of teaching materials were students of Cirebon Cendekia Vocational School and Kamplongan Indramayu Maritim Vocational School.

The instruments in this study were interviews that were used to explore problems of learning in schools, guidelines for analysis to analyze the values of local wisdom in folklore, guidelines for the validation of teaching materials to measure the validity of teaching materials, and tests used to measure the success of learning in using prototype materials teach folklore. Data collected from the results of the interviews were analyzed to obtain a synthesis of learning, while data from the analysis of folklore was used as a starting point for the development of folklore teaching materials in high school or vocational high school. Data from the results of the test implementation of learning to measure the effectiveness of teaching materials are processed using t-test or significance test of two means.

\section{Result and Discussion}

Based on an analysis of folklore it is known that the structure of folklore has a compatibility with the structure of literature so that it can be used as learning material for students. Based on the analysis of the structure of folklore literature from Cirebon and Indramayu, it can be stated that folklore belongs to the type of literature, because it has literary elements as well as the types of prose works. The structure of folklore from Cirebon and Indramayu consists of background, plot, characterization, and theme. However, not all folklore has complete elements as the elements in prose literary works. Therefore, based on the results of the analysis of the completeness of the literary structure, six folklore stories were chosen which could be developed into teaching materials for folk certificates in high school / vocational school. Literary elements in the folklore above can be analyzed based on its constituent elements, sothat this folklore can be a teaching material for folklore texts. The folklore from Cirebon and Indramayu which has a complete 
structure is as set out in table 1 below.

Table 1. Results of Analysis of Structure of Folklore in Cirebon.

\begin{tabular}{|c|c|c|}
\hline No & Title of Folklore & Forming Strukture \\
\hline 1 & Nyi Mas Gandasari & $\begin{array}{l}\text { Place setting: NegeriPaseh, Negeri Cirebon, Sheikh DatukSoleh's House, Cirebon State Boundary, Cave. Timeline: 15th } \\
\text { century. } \\
\text { Theme: The power of Nyi Mas Gandasari } \\
\text { Characterizations: Nyi Mas Gandasari, Syekh DatukSoleh, Syekh Magelung Sakti, Sunan Kalijaga, Ki Gede } \\
\text { Pekandangan, Ki Dampu Awang, Ki Gede Bungko, and Prabu Cakraningrat. } \\
\text { Plot and storyline: plot forward, the series of stories runs from beginning to end. } \\
\text { Message: emancipation of women, obey the rules, }\end{array}$ \\
\hline 2 & Mbah Kuwu Sangkan & $\begin{array}{l}\text { Place Setting: Gunung Jati, Cirebon Coast, Cirebon Girang. Setting time: } 38 \text { years. } \\
\text { Theme: serve parents, carry out the teacher's commands, realized their ideals. } \\
\text { Characterizations: Sheikh Nurjati, MbahKuwuSangkan, Ki GedeAlang-alang, Nyi Mas Rarasantang. } \\
\text { Plot and Storyline: MbahKuwuSangkan's journey in broadcasting Islam. } \\
\text { Message: everyone must have the intention to succeed to reach their goals. }\end{array}$ \\
\hline 3 & Baridindan Ratminah & $\begin{array}{l}\text { Place Setting: Jagapura Coastal Cirebon Beach. Time setting: tonight. } \\
\text { Theme: the most beautiful love story } \\
\text { Characterizations: Bapak Dam, Baridin, Gemblung, Ratminah. } \\
\text { Plot and groove: the groove contains elements of tension and impromptu. } \\
\text { Message: Be patient and trust in facing the test that befalls, because love cannot be forced and it has been determined } \\
\text { that humans live in pairs. }\end{array}$ \\
\hline
\end{tabular}

Other folklore originating from Cirebon Regency and has complete literary structure titled: Mesjid Sang Cipta Rasa, Sejarah Situs Mari Kangen, Misteri Patung Perawan Sunti, Sejarah Makam si Jabang Bayi. This folklore is still in the form of oral literature so that it is obtained from interviews with community leaders in the area. However, the building elements are complete and contain moral values as local wisdom.

Meanwhile, the results of the analysis of the structure and language of Indramayu folklore obtained the following results.

Table 2. Results of Analysis of Structure of Folklore in Indramayu.

\begin{tabular}{|c|c|c|}
\hline No & Title of Folklore & Forming Structure \\
\hline 1 & Ki Bajagdan Ki Gedog & $\begin{array}{l}\text { Setting: the village of Rambat is precisely at Ki Bajag's house. The background of this story is not explicitly described. } \\
\text { However, if we look at the events that occur, the story is set in the afternoon. } \\
\text { Theme: On this earth there is not a single greatest human being. } \\
\text { Characterization: Ki Bajag, Ki Gedog, Ki Bajag's Wife. } \\
\text { Plot and Storyline: in the form of a forward plot, the series of stories runs from beginning to end } \\
\text { Message: we must not be arrogant just because we have strengths. All humans are equal before God. } \\
\text { a. Place Setting: Jatisawit Village. Time setting: morning and evening (bright moon). }\end{array}$ \\
\hline 2 & $\begin{array}{l}\text { BedugKeramat: } \\
\text { JokoBadul }\end{array}$ & $\begin{array}{l}\text { Spiritual setting: the wedding party tradition of the local community for up to seven days and nights. } \\
\text { Theme: always be kind to anyone, especially to people who have cared for and raised parents. } \\
\text { Characterizations: Joko Bajul, Katijah, Ki Kamal, Ki Sardana, and NyiSanti. } \\
\text { Plot and groove: in the form of a forward groove, because the series of stories runs from beginning to end. In the plot } \\
\text { contains elements of tension and impromptu. }\end{array}$ \\
\hline 3 & AsalUsulPedatiKuno & $\begin{array}{l}\text { Message: to get something desired, it must be tried and done honestly. } \\
\text { Location setting: Desayaryar, Cirebon, Roban I areas, and Kapetak. Time setting: on Sunday, } 1486 \text { M. } \\
\text { Theme: Do not be easily provoked emotions let alone let out words that endanger yourself. } \\
\text { Characterizations: Putri, Oongtien, Commander Lie Guacang, Commander Lie Guanhin, Commander Tiampokwang } \\
\text { / Dampuawang, Ki Badur, Nyi Balimbing, Grandpa Kuwu Cirebon II, Ki Dongkala, Ki Sultan Cirebon and Pangeran } \\
\text { Suramadi. } \\
\text { Plot or groove: forward groove. } \\
\text { Mandate: we should always remember God so that all problems are facilitated. }\end{array}$ \\
\hline
\end{tabular}

From each of these folklore there are moral values that can be used as examples or role models for students. These moral values can be used as a theme for the development of short stories as learning outcomes in developing skills in folklore text material. Students will also know the setting of a story that they are familiar with, for example the names of places. Characterizations in folklore also use the names of figures who are generally known by students so that for them the story is not just a fiction but is related to the lives of the people they know. Likewise with the plot and complementary themes in presenting ideas that have moral values as local wisdom.
From the analysis of basic competencies in the curriculum, folk text texts can be developed that are adjusted to the basic competencies in the curriculum and are linked to character ducation that presents local wisdom values. Basic competency development starts from cognitive development, then psychomotor development. Each competency development is directed at written and oral language skills.

The development of these competencies uses teaching materials as scaffolding in learning. The development of the design of teaching materials for folklore text for vocational students is arranged as the following mind map: 


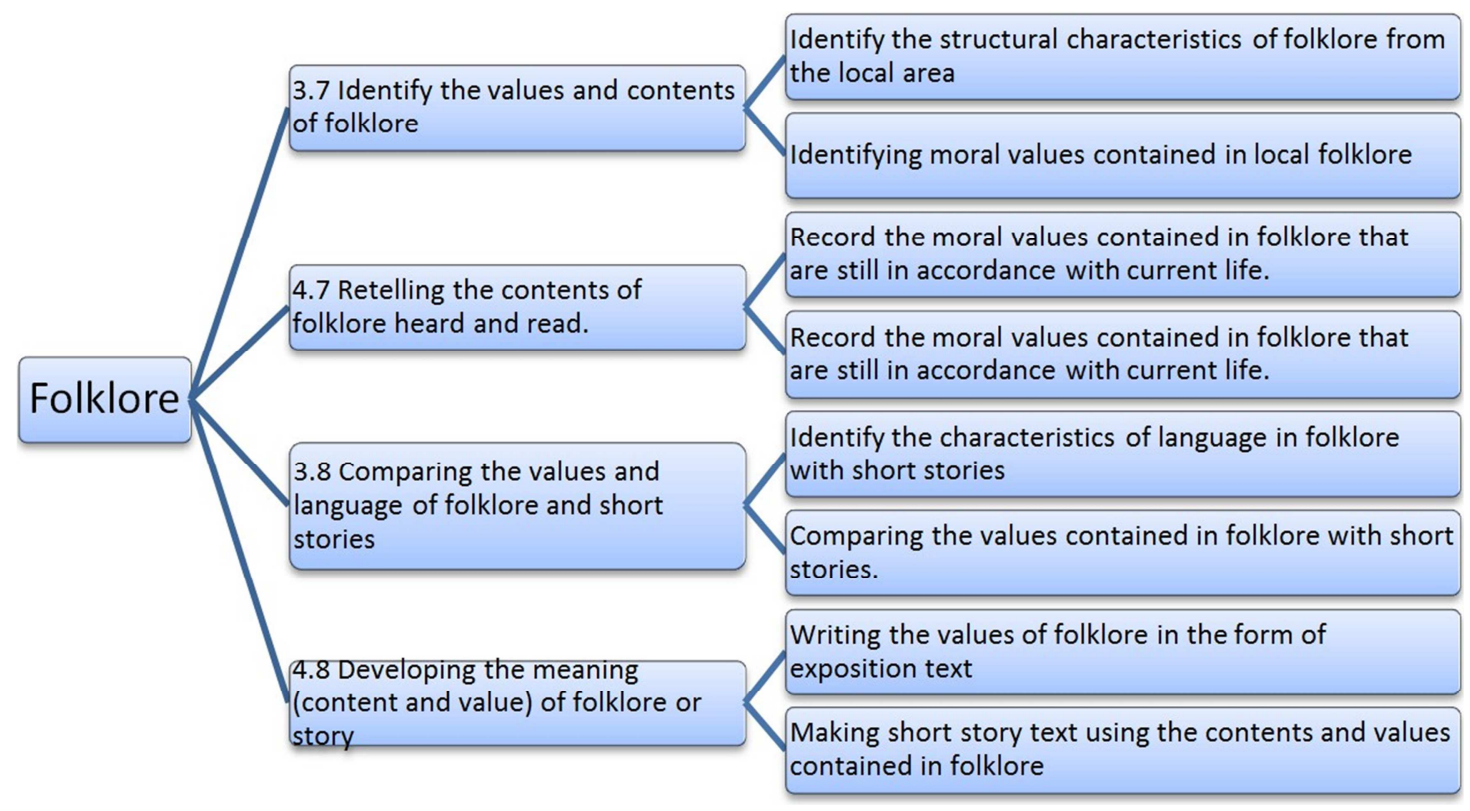

Figure 1. Mind Map of Folklore Teaching Material.

The teaching material developed was subsequently validated by experts and their eligibility practitioners. The components used to validate the feasibility of teaching materials are material or content, presentation, language, and graphics. The total score multiplied by the weight of all components is a maximum of 100 . From the measurements made by experts or academics reached a score of 87.5 while the results of measurements made by teachers who have experienced more than five years reached a score of 92.0. Thus obtained an average of 89.75 which is included in the category as teaching materials that have high eligibility.

Based on the results of the trial application of teaching materials loaded with local wisdom in SMK Cendekia Cirebon and SMK NU Maritim Kamplongan Indramayu it is known that folklore teaching materials extracted from the local community environment where students live get effective learning outcomes This is based on a comparison between teaching materials used in the experimental class and teaching materials used in the control class. Comparison is done by calculating the average value of student learning outcomes then compared using the ttest formula at a significance level of $95 \%$. Based on these calculations, it is known that $\mathrm{t}$ arithmetic is greater than the value of $t$ table, so it can be stated that the difference between the two classes can be trusted.

\section{Discussion}

Based on the description of the results of an analysis of folklore that can be collected from the community, it can be stated that folklore that developed in Cirebon and Indramayucan still be passed on to future generations. Data obtained from the story collection book and from the results of interviews with community leaders can be sorted based on the completeness of the literary structure as the story builder. Folklore that has a complete structure there are moral values that can be obtained from the character of the characters contained in a story, both from the dialogue conducted and from the setting and storyline. From the complete literary structure it can be found moral values contained therein. These moral values are still relevant to good values in today's life that can be emulated. These moral values can be used as character education for students through learning folklore materials developed from folk tales around the students' environment. Character education that is carried out through learning folklore texts will be easier to apply than delivering advice and directions to students.

The use of language elements can still be understood by readers today, there are only a few vocabulary in written folklore whose understanding must be based on the context of the sentence. Unlike the folklore told verbally by community leaders, maybe because he recounts oral stories that have been heard from his parents so he can retell using the language chosen by him.

Teaching materials developed must be able to provide complete information, inspire and motivate students to develop their creativity. Teaching material folklore developed from the student environment makes it easier for students to understand the background and characterizations so that the storyline and themes of the folklore are easily understood by students. If the folklore is easy to understand, students' interest in learning will increase. Based on the validation of the material expert and the teacher as a learning practitioner who reviews teaching material from the appropriateness of the material or content, presentation, language, and graphics shows that the teaching material must have material truth and concept suitability. In addition, teaching materials developed must have an implicit or explicit purpose especially in developing the character of students through messages of moral values contained in a story. These moral values are local wisdom that should be developed through education.

The development of folklore text teaching materials that 
contain local wisdom to provide character education to students can overcome the limitations of teaching materials that have been a problem for teachers. The problem of teaching materials that are less varied and not interested by students can be overcome by producing this teaching material. Likewise, when a school experiences difficulties in providing teaching materials for Indonesian subjects, it can be overcome by the results of developing teaching materials that are extracted from local wisdom around students.

The results of the trial of teaching materials show that teaching materials developed from folklore that develop in students' environments attract students more interest in learning than folklore they do not know. The unfamiliar folklore originated in Sumatra or Kalimantan, so that students' efforts to connect conditions or locations as background stories with real conditions at this time can increase motivation for learning. Prototype teaching materials folklore that are arranged according to the needs of students and teachers have high effectiveness. Likewise, if prototypes of folklore teaching materials developed as teaching materials extracted from the student environment will further enhance the effectiveness of learning objectives. Thus, in addition to analyzing the needs of students and teachers in preparing teaching materials, it is also necessary to provide teaching materials sourced from folklore that live in the student environment. The use of place settings and characterizations in folklore can motivate students to learn optimally in realizing the achievement of basic competencies.

\section{Conclusion}

Based on the presentation and discussion of the development of folklore teaching materials containing local wisdom, it can be summarized as follows:

Folklore that lives in Cirebon and Indramayu regencies has a structure like the literary text in general so that it can be used as teaching material in schools. The folklore structure as a literary structure will make it easier for students to take advantage of it, even the language used can still be understood. The language elements used in folklore can still be understood by students so that the use of pronouns, adverbial phrases, material verbs, or temporal conjunctions can still be understood by students.

Teaching materials that are developed based on folklore that have local wisdom should be used as teaching materials in SMK. This material that contains local wisdom can be used by teachers as character education for students, educating positive values, good behavior, noble morals and national dignity. This is based on the results of validation from experts and practitioners which are reviewed based on the content, presentation, language, and graphics of the teaching material which exceeds the minimum requirements.

Based on the results of trials in SMK Cendekia Cirebon and SMK NU Maritim Kamplongan Indramayu it is known that the teaching material can be used effectively in improving students' ability to produce literary works, especially writing short stories using basic ideas from folklore.

\section{References}

[1] E. Oring, Legendry and the Rhetoric of Truth. Journal of American Folklore, Columbus, vol. 121, Iss. 480: 127-166, 251, 2008.

[2] S. Kusmana and Jaja. Study of Legends and Folklores as Efforts to Develop Instructional Materials in High Schools. Advances in Social Science, Education and Humanities Research, Volume 297. April, 2019. Web: https://doi.org/10.2991/icille-18.2019.80. 2019.

[3] Balitbang, Panduan Pengembangan Pendidikan Karakterpada Satuan Pendidikan Dasardan Menengah. Jakarta: Balitbang Kemdikbud. 2010.

[4] R. Finnegan, "Secrets of the Extraordinary Ordinary: The Revelations of Folklore and Anthropology," School of History, Religious Studies, Sociology, Social Policy and Criminology, Faculty of Arts \& Social Sciences, The Open University, Milton Keynes MK7 6AA, UK, 2018.

[5] T. Brian, Material Development for Language Learning and Teaching. Language Teaching. Cambridge 45 (2). April 2012 143-179. 2012.

[6] C. Du Toit, Towards a Vocabulary for Visual Analysis: Using Picture Books to Develop Visual Literacy with Pre-Service Teachers. Mousaion, 32 (2). 2014.

[7] J. Danandjaja, Folklor Indonesia. Jakarta: PT PustakaUtamaGrafiti. 1994.

[8] J. G. Liendo, "Teachers, Folklore, and the Crafting of Serrano Cultural Identity in Peru," Latin American Research Review, Washington University in Saint Louis. US. 52 (3). pp 378-392, 2017. DOI: https://doi.org/10.25222/larr.78. 2017.

[9] Iskandarwasid dan D. Sunendar, Strategi Belajar Pembelajaran Bahasa. Bandung: PT Remaja Rosda Karya. pp. 171-172. 2012.

[10] I. Lestari, Pengembangan Bahan Ajar Kompetensi (sesuai dengan Kurikulum). Padang: Akademia Permata. 2013.

[11] Hamdani. Strategi Belajar Mengajar. Bandung: Penerbit CV. Pustaka Setia. 2011.

[12] S. Nag, M. J. Snowling, and J. Mirković, The role of Language Production Mechanisms in Children's Sentence Repetition: Evidence from an Inflectionally Rich Language. Applied Psycholinguistics, 39 (2), 303-325 J. 2018.

[13] S. Kusmana, Kretivitas Menulis. Yogyakarta: Penerbit Ombak. 2014.

[14] M. Janice and G. Juliet, Cognitive and language acquisition in typical and aided language learning: A Review of Recent Evidence from an Aided Communication Perspective. Child Language Teaching and Therapy; London Vol. 25, Iss. 1, February. 2009.

[15] C. Dalton-Puffer and U. Smith, Content and Language Integrated Learning: A Research Agenda. Language Teaching. $\begin{array}{llll}\text { Vol.46 (04) October } 2013 . & \text { DOI: }\end{array}$ $10.1017 / 80261444813000256$.

[16] S. Kusmana, Orientasi Pelajaran Bahasa Indonesia dalam Kurikulum 2013. Prosiding Seminar Nasional. Universitas Ahmad Dahlan. Yogyakarta. 2016. 
[17] Broch, Haroll Beyer. 1995. Minahasa Past and Present: Tradisional and Transition in an Outer Island Region of Indonesia. The Journal of Asian Studies. Nov 1996: 55.4; Arts and Humanities Databased. Pg 1082.

[18] Ch. Akoma, Folklore and the African-Caribbean Narrative Imagination: The example of Roy Heath Research in African Literatures; Bloomington Vol. 29, Iss. 3, (Fall 1998): 82-97.

[19] C. Lynn, On the Political Uses of Folklore: Performance and Grassroots Feminist Activism in India Garlough, Jurnal of American Folklore; Columbus Vol. 121, Iss. 480: 167-191, 251. 2008.

[20] Simon J. Bronner, The Challenge of American Folklore to the Humanities School of Humanities, American Studies Program, The Pennsylvania State University, Middletown, PA 17057 4898, USA; 2018.

[21] M. Mustari, NilaiKarakter Refleksi Untuk Pendidikan Karakter. Yogyakarta: Laksbang Pressindo. 2011.

[22] E. Dabrowska, Experience, Aptitude, and Individual Differences in Linguistic Attainment: A Comparison of Native and Nonnative Speakers. Language Learning. A Jornal of Research Language Studies. University of Michigan. September 2018, p 1-29. 2018.
[23] R. Sibarani, Kearifan Lokal: Hakikat, Peran, dan Metode Tradisi Lisan. Jakarta: Asosiasi Tradisi Lisan. 2012.

[24] D. Natalia, Pengembangan Bahan Ajar Sastra Berbasis Cerita Rakyat Banyumas Untuk SiswaKelas V SD. Purwokerto: Thesis, Universitas Muhammadiyah Purwokerto. 2017.

[25] L. O. Talami, et. al., Kearifan Lokal dalam Kebudayaan Suku Bangsa - Suku Bangsa Sulawesi Tenggara. Sulteng: Lembaga Penelitian dan Pengembangan Sumber Daya Bangsa. 2010.

[26] C. S. Kawan, Perspectives on Contemporary Legend 28th Conference of the International Society for Contemporary Legend Research Fabula; Berlin Vol. 51, Iss. 3/4: 303-306. 2010 .

[27] W. R. Borg \& M. D. Gall, Educational Research: An Introduction, Fifth Edition. New York: Longman. 1983.

[28] N. S. Sukmadinata, Metode Penelitian Pendidikan. Bandung: Remaja Rosda Karya dan Program Pascasarjana UPI Bandung. 2010.

[29] Sugiyono, Metode Penelitian Pendidikan: Pendekatan Kuantitatif, Kualitatif, dan R \& D. Bandung: Alfabeta. 2010. 